\title{
Relation between dietary lipid level and voluntary feed intake, growth, nutrient gain, lipid deposition and hepatic lipogenesis in rainbow trout
}

\author{
Anne GÉLINEAU ${ }^{\mathrm{a}}$, Geneviève CORRAZE ${ }^{\mathrm{b} *}$, Thierry BOUJARD ${ }^{\mathrm{b}}$, \\ Laurence LARROQUET $^{\mathrm{b}}$, Sadasivam KAUSHIK ${ }^{\mathrm{b}}$
}

\author{
${ }^{a}$ Aquitaine Aquaculture Sarl, 1 rue Marcel David, 40004 Mont-de-Marsan, France \\ ${ }^{\mathrm{b}}$ Unité mixte INRA-IFREMER de Nutrition des Poissons, Unité de recherches en Hydrobiologie, \\ INRA, BP 3, 64310 Saint-Pée-sur-Nivelle, France
}

(Received 29 August 2001; accepted 6 November 2001)

\begin{abstract}
Four diets with differing lipid contents (15, 20, 25 or 30\% DM) were tested on small (initial body weight: $27 \mathrm{~g}$ ) and larger (IBW: $93 \mathrm{~g}$ ) rainbow trout (Oncorhynchus mykiss) fed on demand or by hand, respectively. In both trials, voluntary feed intake was inversely related to dietary lipid levels. Protein efficiency increased when dietary fat content increased. Final whole-body lipid content was positively related to dietary lipid levels. The main sites of lipid storage were visceral adipose tissue and to a lesser extent muscle. Increased fat deposition in the visceral cavity of young trout was due to both hyperplasic and hypertrophic responses and in larger trout mostly due to a hypertrophic response. Liver activities of glucose-6-phosphate dehydrogenase and fatty acid synthetase were negatively correlated with fat intake and positively with starch intake, whereas malic enzyme was little affected by dietary treatments.
\end{abstract}

rainbow trout / dietary lipid / feed intake / lipid deposition

Résumé - Relation entre le taux de lipides alimentaires et l'ingestion volontaire, les performances de croissance, les dépôts lipidiques et la lipogénèse hépatique chez la truite arc-en-ciel. Quatre régimes différant par leur contenu lipidique (15, 20, 25 et $30 \%$ MS) sont testés chez des truites arc-en-ciel (Oncorhynchus mykiss) de petite taille (poids initial : $27 \mathrm{~g}$ ) ou plus grandes (p.i. : $93 \mathrm{~g}$ ) nourries respectivement à la demande ou à la main. Dans les deux cas, l'augmentation de la teneur en lipides du régime diminue l'ingestion volontaire et augmente l'efficacité protéique et le gain lipidique. La teneur corporelle finale en lipides est positivement corrélée aux taux de lipides alimentaires. Les sites principaux de stockage des lipides sont le tissu adipeux péri-viscéral et dans une moindre mesure le muscle. L'élévation des dépôts péri-viscéraux est due, chez les

\footnotetext{
* Correspondence and reprints

E-mail: corraze@st-pee.inra.fr
} 
truitelles, à une hypertrophie et une hyperplasie concomitante des cellules adipeuses et chez les plus grandes truites essentiellement à une hypertrophie des cellules existantes. L'activité hépatique de la glucose-6-phosphate déshydrogénase et de l'acide gras synthétase est inversement corrélée aux quantités de lipides ingérés alors que celle de l'enzyme malique est peu affectée par le régime.

\section{truite arc-en-ciel / lipides alimentaires / ingestion volontaire / dépôt lipidique}

\section{INTRODUCTION}

Besides obtaining more precise information on the optimal protein and energy requirements of fish, the need for practical means of reducing uneaten feed waste and digestive and metabolic losses of nutrients is well recognised [21, 22]. In fish, proteins are used as a major energy source and the protein level required for maximal growth is considered higher than that of terrestrial farm animals [29, 84]. It is well established that protein retention in fish can be improved by increasing the relative contribution of non-protein energy (fats or digestible carbohydrates) in the diets [22, 58, 63, 80, 92].

Fats yield greater energy per unit weight than carbohydrates and digestibility of dietary fish or vegetable oils is high in the salmonid species (80 to 95\%) [22] whereas digestibility of carbohydrates is much more variable depending on the botanical source as well as on the degree of gelatinisation $[12,13,58,85]$. For these reasons, among the two conventional energy sources, fats are preferentially incorporated to salmonid diets to increase the digestible energy levels.

Under self-feeding $[15,30,41,46,61$, 74] or hand-feeding (to satiation) conditions [31, 32, 40, 63], a number of fish species have been reported to regulate their feed intake in accordance with their energy requirements, but the mechanisms involved in such a process remain unknown.

Although the use of high energy diets can increase protein efficiency and decrease nitrogen discharge, one additional prerequisite is that it does not affect fish quality.
Several studies have shown that increasing fat content of the diets enhances fat deposition [26, 28, 47, 86, 91]. However, the relative importance of the lipid deposition sites varies markedly among fish species and includes the liver, visceral adipose tissue or muscle [1]. In salmonids, mesenteric fat is the main lipid storage site, possessing a virtually unlimited lipid storage capacity [81]. In mammals, the growth of adipose tissues is generally explained by the increase in size (hypertrophy) of adipose cells [77, 79], since the number of cells is established early in development [14, 64], but hyperplasic growth of the adipose tissue remains possible in old subjects in response to lipid or carbohydrate enriched diets [36, 37]. In fish, available information is limited, but an increased storage capacity in visceral adipose tissue by dietary manipulations or environmental conditions seems to be comparable to that of higher vertebrates, resulting from both mechanisms [35].

In fish, the liver and muscle are considered secondary lipid deposition sites and adapted for short-term storage [81]. As reported by Lin et al. [68] who compared lipid biosynthesis by the liver and visceral adipose tissue from coho salmon, Oncorhynchus kisutch, and confirmed by further studies in other fish species [7, 43, 67], the liver accounts for more de novo lipid synthesis than the adipose tissue. Body lipids can also be synthesised de novo from other carbon donors, such as carbohydrates or amino acids, as shown by the fat gain / fat intake ratio above $100 \%[18,60]$. Dietary manipulations have been demonstrated to 
affect lipogenesis in the same manner as in mammals. An increase in dietary fat level and a concomitant decrease in digestible carbohydrate content has been shown to depress the activity of different lipogenic enzymes in coho salmon, Oncorhynchus kisutch [68, 69], channel catfish, Ictalurus punctatus [67] and in juvenile European sea-bass, Dicentrarchus labrax [33]. However, lipogenesis seems to be less severely controlled by the dietary fat level in fish than in mammals, since more than a $10 \%$ increase in dietary lipid content is required in fish $[19,43]$ compared to only a $3-4 \%$ increase in sheep and rats [20] to depress de novo fatty acid synthesis.

The purpose of the investigations reported here was to examine the relation between dietary fat level and voluntary feed intake, growth and adiposity in rainbow trout at a young stage and at a marketable size. A second objective was to evaluate the effects of an increased dietary lipid level on hepatic lipogenesis and tissue fat deposition.

\section{MATERIALS AND METHODS}

\subsection{Diets, feeding methods and growth trial}

Rainbow trout (Oncorhynchus mykiss) were fed isonitrogenous diets formulated to contain increasing lipid levels of 150, 200, 250 and $300 \mathrm{~g}$ per $\mathrm{kg}$ of dry matter (T15, T20, T25 and T30; Tab. I). All the diets

Table I. Ingredients and proximate composition of the experimental diets.

\begin{tabular}{|c|c|c|c|c|}
\hline & $\mathrm{T} 15$ & $\mathrm{~T} 20$ & $\mathrm{~T} 25$ & $\mathrm{~T} 30$ \\
\hline \multicolumn{5}{|l|}{ Ingredients $\left(\mathrm{g} \cdot \mathrm{kg}^{-1}\right)$} \\
\hline Fish meal $^{\#}$ & 351 & 380 & 403 & 425 \\
\hline Soluble fish protein concentrate (CPSP G) & 50 & 50 & 50 & 50 \\
\hline Fish oil & 100 & 149 & 198 & 247 \\
\hline Extruded peas (Aquatex, France, CP: 217) & 249 & 191 & 119 & 48 \\
\hline Soybean meal (CP: 451) & 220 & 200 & 200 & 200 \\
\hline Vitamin mixture* & 10 & 10 & 10 & 10 \\
\hline Mineral mixture ${ }^{\dagger}$ & 10 & 10 & 10 & 10 \\
\hline Binder (Sodium alginate) & 10 & 10 & 10 & 10 \\
\hline \multicolumn{5}{|l|}{ Proximate composition } \\
\hline Dry matter $(\mathrm{DM})\left(\mathrm{g} \cdot \mathrm{kg}^{-1}\right)$ & 923 & 937 & 931 & 924 \\
\hline Crude protein $(\mathrm{N} \times 6.25)\left(\mathrm{g} \cdot \mathrm{kg}^{-1} \mathrm{DM}\right)$ & 437 & 432 & 433 & 425 \\
\hline Crude fat $\left(\mathrm{g} \cdot \mathrm{kg}^{-1} \mathrm{DM}\right)$ & 145 & 197 & 250 & 302 \\
\hline $\operatorname{Starch}\left(g \cdot \mathrm{kg}^{-1} \mathrm{DM}\right)$ & 142 & 104 & 76 & 44 \\
\hline Gross energy $\left(\mathrm{kJ} \cdot \mathrm{g}^{-1} \mathrm{DM}\right)$ & 20.2 & 21.8 & 22.4 & 23.3 \\
\hline Crude protein $(\mathrm{mg}) /$ Gross energy $\left(\mathrm{mg} \cdot \mathrm{kJ}^{-1}\right)$ & 21.6 & 19.8 & 19.3 & 18.2 \\
\hline Digestible protein (DP) $\left(\mathrm{g} \cdot \mathrm{kg}^{-1} \mathrm{DM}\right)^{\S}$ & 40.1 & 39.8 & 39.8 & 39.1 \\
\hline Digestible energy (DE) $\left(\mathrm{kJ} \cdot \mathrm{g}^{-1} \mathrm{DM}\right)^{¥}$ & 17.1 & 19.5 & 20.3 & 21.4 \\
\hline $\mathrm{DP} / \mathrm{DE}\left(\mathrm{mg} \cdot \mathrm{kJ}^{-1}\right)$ & 23.4 & 20.4 & 19.6 & 18.3 \\
\hline
\end{tabular}

${ }^{\#}$ Herring, crude protein $(\mathrm{CP})>700 \mathrm{~g} \cdot \mathrm{kg}^{-1}$.

* As per NRC [71].

$\dagger$ Per kg diet: $1.12 \mathrm{~g} \mathrm{CaCO}_{3}(40 \% \mathrm{Ca}) ; 0.62 \mathrm{~g} \mathrm{MgO}(60 \% \mathrm{Mg}) ; 0.1 \mathrm{~g}$ ferric citrate; $0.2 \mathrm{mg} \mathrm{KI}(75 \% \mathrm{I}) ; 0.2 \mathrm{~g} \mathrm{ZnSO}_{4}$ $(36 \% \mathrm{Zn}) ; 0.15 \mathrm{~g} \mathrm{CuSO}_{4}(25 \% \mathrm{Cu}) ; 0.15 \mathrm{~g} \mathrm{MnSO}_{4}(33 \% \mathrm{Mn}) ; 2.5 \mathrm{~g} \mathrm{Ca}_{3}\left(\mathrm{PO}_{4}\right)_{2}(20 \% \mathrm{Ca}, 18 \% \mathrm{P}) ; 1 \mathrm{mg} \mathrm{CoSO}$; $1.5 \mathrm{mg}$ sodium selenite ( $30 \% \mathrm{Se}) ; 0.45 \mathrm{~g} \mathrm{KCl} ; 0.2 \mathrm{~g} \mathrm{NaCl}$.

$\$$ DP was calculated assuming a digestibility coefficient value of $92 \%$ [22].

$¥ \mathrm{DE}$ was calculated assuming digestibility coefficient values of $85 \%$ for T15 diet, $89.5 \%$ for T20 diet, $90.5 \%$ for T25 diet and $91.5 \%$ for T30 diet [22]. 
were made into dry pellets using a laboratory pelleting machine. The pellet diameter was $3 \mathrm{~mm}$ in trial 1 and 5 to $7.5 \mathrm{~mm}$ in trial 2 .

The first trial was conducted at the INRA facilities of Saint-Pée-sur-Nivelle (PyrénéesAtlantiques, France) for a period of 9 weeks. The artificial photoperiod was composed of $13 \mathrm{~h}$ light / $11 \mathrm{~h}$ dark (light on at 06:30) with an artificial dawn and dusk of 30 min each. Tanks $(100 \mathrm{~L})$ were supplied with fresh river water $\left(12.5 \pm 1.5^{\circ} \mathrm{C}\right.$; flow rate $\left.5 \mathrm{~L} \cdot \mathrm{min}^{-1}\right)$. Each tank was equipped with a demandfeeder system (Imetronic Sarl, France), composed of a trigger placed $5 \mathrm{~mm}$ above the water surface, an interface that conditioned the signal from the trigger and a control software that recorded the hour and origin of the signals and controlled the feeder [16]. The feeder delivered a predetermined amount of food (around $0.5 \mathrm{~g}$ ) after each trigger actuation. Trout with an initial average body weight of $27 \mathrm{~g}$ were randomly allotted into 12 groups of 35 fish each. Free access to food was for two periods of $2.5 \mathrm{~h}$ each per day (07:00-09:30 and 17:00-19:30). Each tank was equipped with a sediment trap, the efficiency in collecting waste feed was the same for all tanks and near $100 \%$.

The second trial was conducted at the INRA experimental fish farm in Donzacq (Landes, France) under a natural photoperiod (February - April) for 12 weeks. Tanks $(500 \mathrm{~L})$ were supplied with fresh spring water $\left(17 \pm 1{ }^{\circ} \mathrm{C}\right.$; flow rate $\left.10 \mathrm{~L} \cdot \mathrm{min}^{-1}\right)$. Trout with an average body weight of $93 \mathrm{~g}$ were randomly distributed into eight groups of 100 fish each. Fish were fed by hand to visual satiation twice daily (09:00 and 16:00).

\subsection{Sample collection}

In both trials, fish biomass was recorded every three weeks and feed intake once a week. On the day the experiment was started, 10 fish were sacrificed by a sharp blow on the head for subsequent initial whole-body composition. At the end of both trials, after the final weighing, five fish per tank were sacrificed for whole-body composition analysis. Visceral adipose tissue was withdrawn on three fish per dietary treatment and immediately fixed in osmic acid solution for subsequent adipose cell analysis.

In trial 2, the liver, viscera and muscles were withdrawn from six fish per dietary treatment, frozen in liquid nitrogen and stored at $-80{ }^{\circ} \mathrm{C}$ prior to total lipid analysis. The livers from six other fish per dietary treatment were withdrawn and immediately treated for lipogenic enzyme activity assays.

\subsection{Analytical methods}

Whole fish bodies were crushed, homogenised and freeze-dried before analysis. Chemical composition of the diets and whole fish was made using the following procedures: dry matter after drying at $105^{\circ} \mathrm{C}$ for $24 \mathrm{~h}$, fat after extraction with petroleum ether by the Soxhlet method, starch by the glucose-amylase-glucose-oxidase method [87], protein $(\mathrm{N} \times 6.25)$ by the Kjeldahl method after acid digestion and gross energy in an adiabatic bomb calorimeter (IKA).

The liver, viscera and muscles were homogenised and total lipids were determined by the method of Folch et al. [38], with chloroform being replaced by dichloromethane, less toxic than the former.

Visceral adipose tissues were treated as described by Fauconneau et al. [35] using the following procedure. Samples of $100 \mathrm{mg}$ of adipose tissues were finely cut, filtered (50 $\mu \mathrm{m}$ nylon screen), rinsed $(\mathrm{NaCl}$, $\left.9 \mathrm{~g} \cdot \mathrm{L}^{-1}\right)$ and fixed for one week in a $1 \%$ osmic acid solution $\left(\mathrm{OsO}_{4}\right.$ in $15 \mathrm{mM}$ sodium phosphate buffer). The fixed tissue was then recovered, filtered (400 $\mu \mathrm{m}$ stainless steel screen) and rinsed with distilled water. The solution was filtered $(0.45 \mu \mathrm{m}$ nitrocellulose filter, Whatman). The recovered adipose cells were suspended and left for one 
week in an $8 \mathrm{M}$ urea solution for dissolution of non-fixed material. Finally the suspension of cells was filtered $(0.45 \mu \mathrm{m}$ nitrocellulose filter) and washed with distilled water containing X100 Triton. The filters were then observed on a light transmission microscope (Wild Heerbrugg) equipped with a camera. The size of each adipocyte was measured by two orthogonal diameters using a digitising table connected to a semi-automatic image analyser (VIDS, Systèmes Analytiques, France), with at least 150 cells being measured on each filter.

For enzyme activity determinations, liver samples were homogenised in three volumes of ice-cold buffer (0.02 M Tris- $\mathrm{HCl}$, $0.25 \mathrm{M}$ sucrose, $2 \mathrm{mM}$ EDTA, $0.1 \mathrm{M} \mathrm{NaF}$, $0.5 \mathrm{mM}$ phenyl methyl sulphonyl fluoride, $0.01 \mathrm{M} \beta$-mercaptoethanol, $\mathrm{pH}$ 7.4). Homogenates were centrifuged at $20000 \mathrm{rpm}$ at $4{ }^{\circ} \mathrm{C}$ for $20 \mathrm{~min}$. Soluble protein content of liver homogenates was determined by the method of Bradford [17]. The lipogenic enzyme activities were assayed on the supernatant using spectrophotometric procedures: glucose-6-phosphate dehydrogenase (G6PD, EC 1.1.1.49) according to the method of Bautista et al. [9], malic enzyme (ME, EC 1.1.1.40) according to Ochoa [72] and by isotopic method: fatty acid synthetase (FAS, EC 2.3.1.38) according to Hsu et al. [51]. Enzyme activity units (IU), defined as $\mu$ moles of substrate converted to the product per min at an assay temperature, were expressed per mg of hepatic soluble protein (specific activity), per gram of liver tissue (wet weight) or calculated per $100 \mathrm{~g}$ fish.

\subsection{Statistical analysis}

Data were analysed by one-way ANOVA using SAS-6.09 (SAS Inst., NC, USA). When $\mathrm{F}$ values indicated significance $(P<0.05)$, the means were compared using the Duncan multiple range test. The correlations between nutrient intake and growth parameters, whole-body or tissue composition and enzyme activities were also determined $(P<0.05$; Pearson test, Prism ${ }^{\circledR}-3.0$, Graphpad Software, San Diego, USA).

\section{RESULTS}

\subsection{Growth performance, intake and nutrient utilisation}

No differences in Final body weights (FBW) were found between the fish fed T15, T20 and T25 diets in either of the trials (Tabs. II and III). However, FBW was higher in the fish fed diet T30 than in those fed the other diets. An increase in dietary lipids caused a significant decrease in voluntary feed intake (VFI) for diets T15, T20 and T25. Daily digestible energy intake (DEI) was enhanced by dietary lipid levels in both trials, whereas this effect was statistically significant only in trial 2 .

In both trials, the best feed efficiency (FE) values were obtained with T25 and T30 diets. Specific growth rate (SGR) and FE were found to be positively correlated with fat intake, and protein efficiency ratio (PER) values and fat gain were generally higher in the fish fed the high fat diets (T25 and T30) than in those fed lower levels of fat (T15 and T20). Significant correlations were found between fat gain and fat intake.

\subsection{Whole-body and tissue composition}

Whole-body lipid contents ranged respectively from 80 to $100 \mathrm{~g} \cdot \mathrm{kg}^{-1}$ and from 135 to $180 \mathrm{~g} \cdot \mathrm{kg}^{-1}$ of fresh weight in trial 1 (FBW: 75-80 g) and 2 (FBW: $>400 \mathrm{~g}$ ) (Tabs. II and III). Lipid and protein contents were found to be significantly correlated (positively for lipid and inversely for protein content) to fat intake in both trials (Tabs. II and III).

Data on the lipid content in different tissues of trial 2 are reported in Table IV. The hepato-somatic index (HSI) and viscerosomatic index (VSI) ranged respectively from 1.1 to $1.2 \%$ and 9 to $13 \%$ body weight. 
A. Gélineau et al.

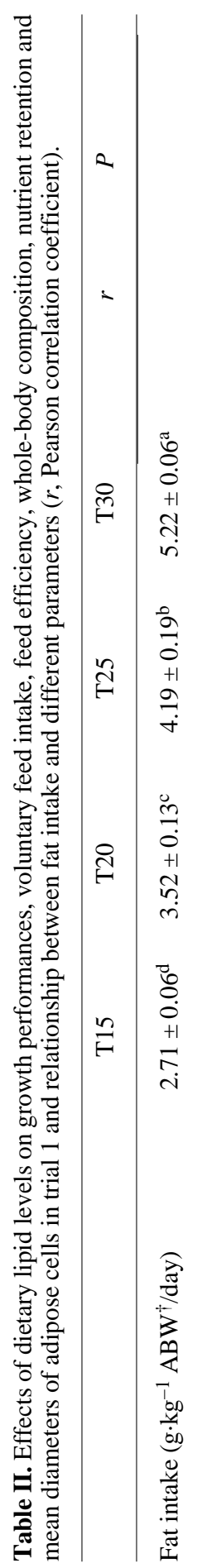

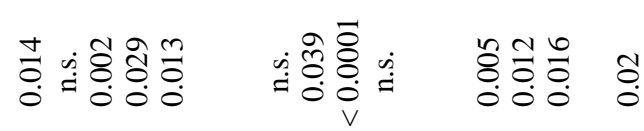

苍 |

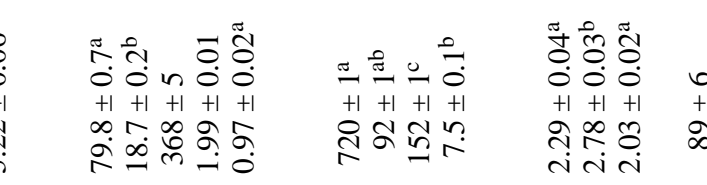

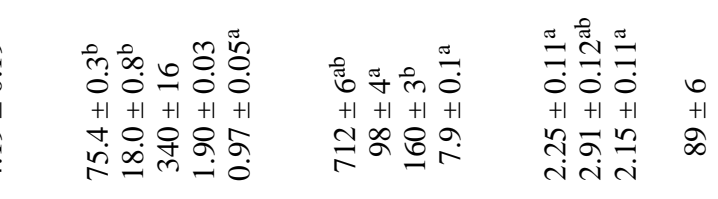

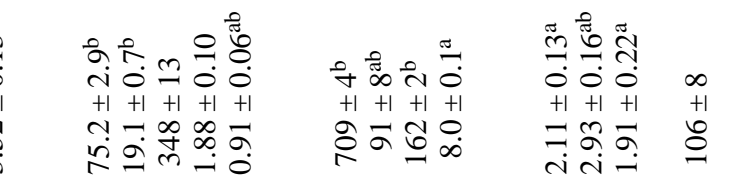

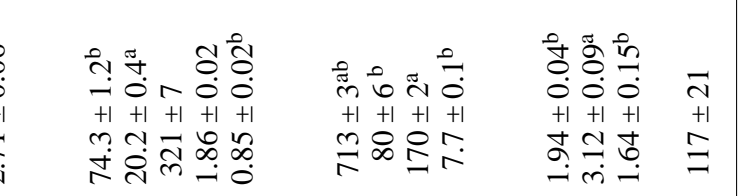

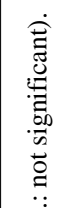


Increased lipid levels in rainbow trout feed

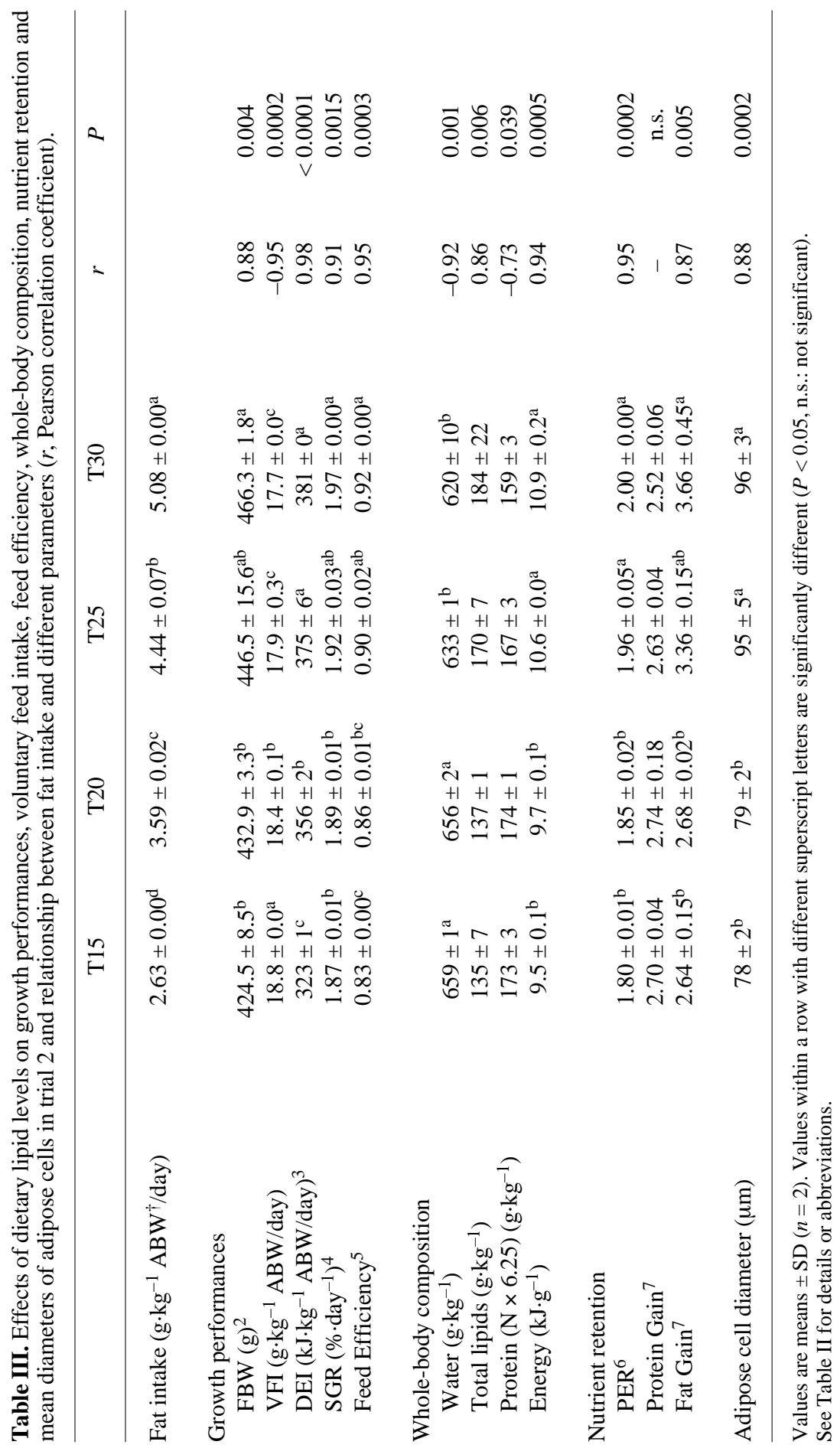


A. Gélineau et al.

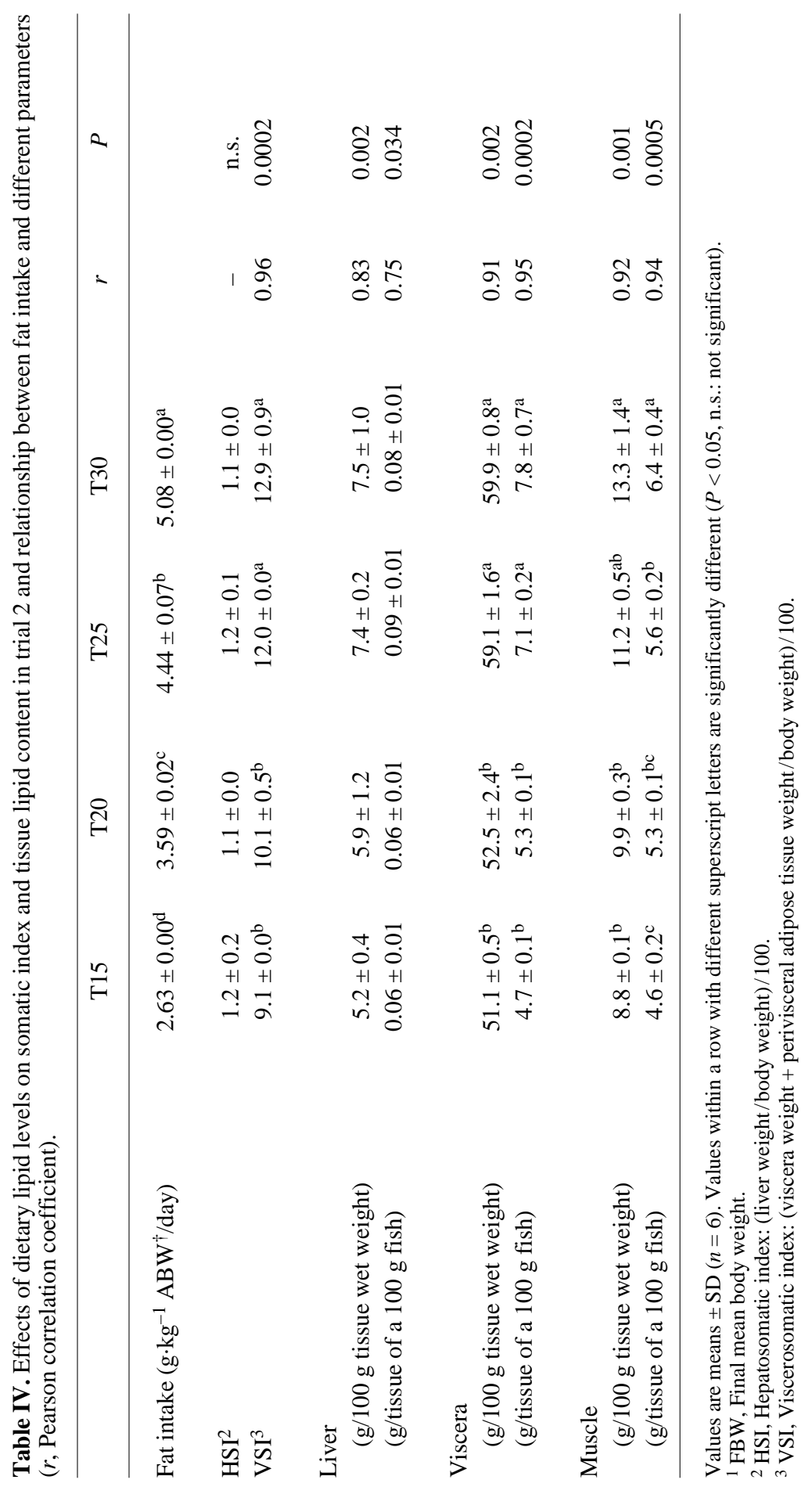


HSI was not significantly affected by dietary treatment. VSI was positively correlated to fat intake. Hepatic fat content ranging from 52 to $75 \mathrm{~g} \cdot \mathrm{kg}^{-1}$ of fresh weight, visceral fat content ranging from 510 to $600 \mathrm{~g} \cdot \mathrm{kg}^{-1}$ of fresh weight and muscle fat content ranging from 90 to $130 \mathrm{~g} \cdot \mathrm{kg}^{-1}$ of fresh weight were found to be positively and strongly correlated with fat intake.

\subsection{Distribution frequencies and means of adipocyte diameters in visceral fat tissues}

Diameters of visceral adipose cells ranged from 25 to $230 \mu \mathrm{m}$ in both trials. In trial 1 , mean adipocyte diameters were not statistically different $(P>0.05)$ among treatments, although they were negatively correlated with fat intake (Tab. II). Inversely, in trial 2, adipose cell diameters were significantly lower with T15 and T20 diets than with T25 and T30 diets (Tab. III).
In trial 1 (Fig. 1A), the percentage of middle size (50 to $150 \mu \mathrm{m}$ ) adipocytes was shown to be correlated with fat intake ( $r=0.96 ; P=0.04)$. In addition, the percentage of large adipocytes $(>150 \mu \mathrm{m})$ was shown to be inversely correlated to fat intake $(r=-0.99 ; P=0.01)$.

In trial 2 (Fig. 1B), small adipocytes were less frequent in trout fed the T30 diet than in the other dietary treatments. Middle size adipose cells were more frequent in trout fed the T30 diet than in the other dietary treatments. The frequency of large adipocytes was higher in trout fed the T25 and T30 diets than in those fed the T15 and T20 diets.

\subsection{Activities of lipogenic enzymes}

Data on the activities of the three lipogenic enzymes assayed in trial 2 are reported as IU per liver in Figure 2 and per mg protein or per $100 \mathrm{~g}$ whole fish in Table V. Among the two NADPH-generating dehydrogenases,
Figure 1. Frequency distributions of adipose cell diameter in perivisceral tissue from trout of $75 \mathrm{~g}$ mean body weight (trial 1, A) and trout of $450 \mathrm{~g}$ mean body weight (trial 2, B). Means of three individuals are given with standard deviations (vertical bars).

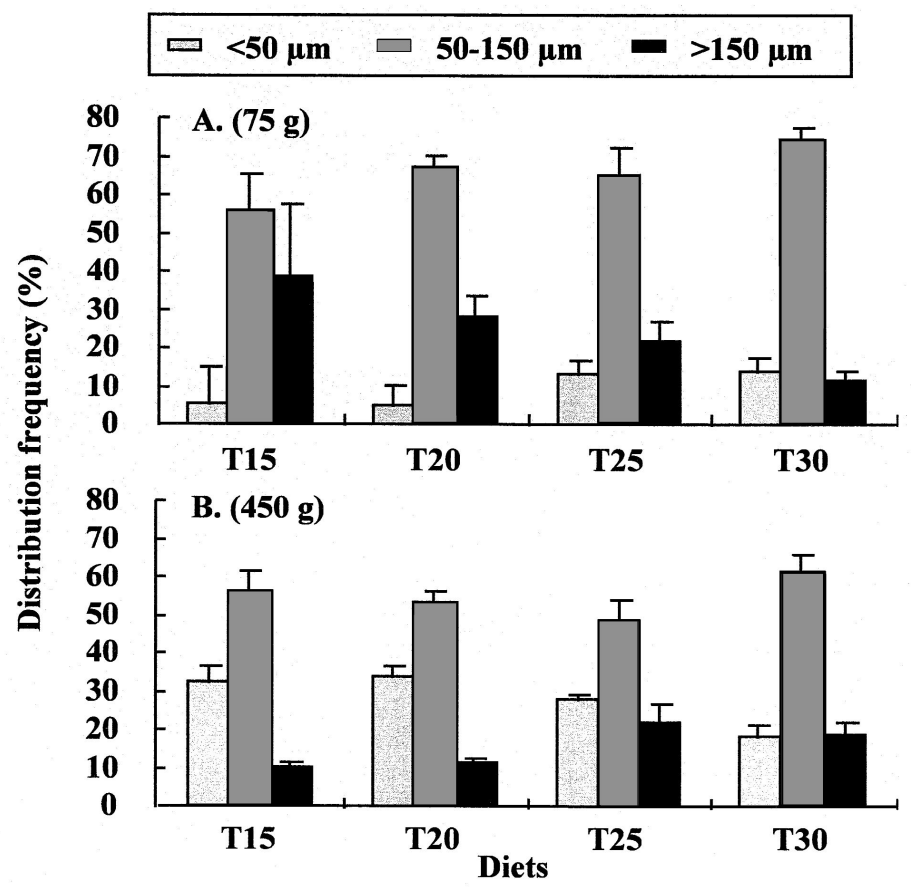




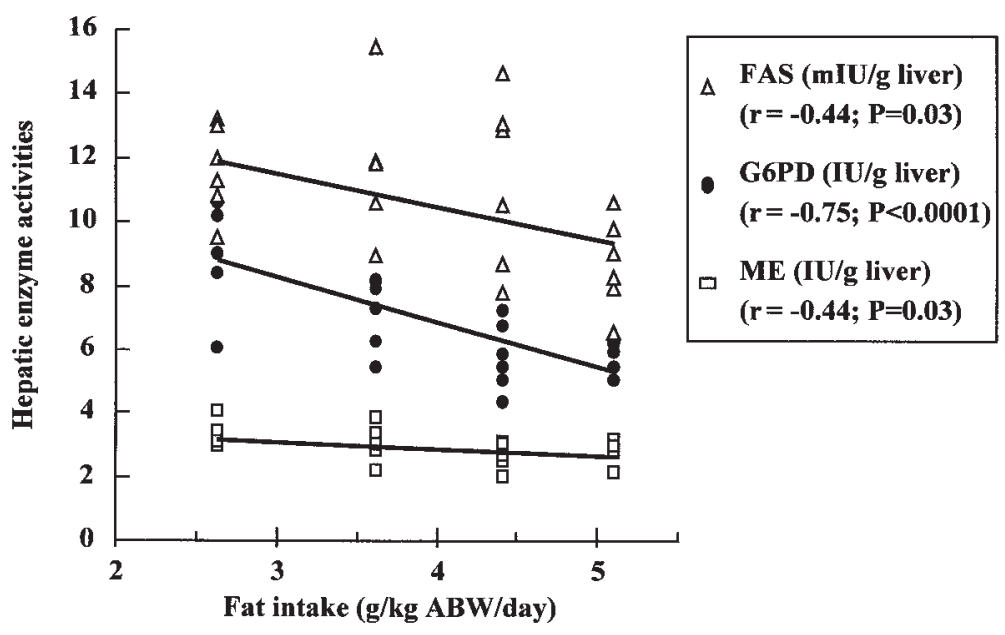

Figure 2. Relation between mean daily fat intake and activities of hepatic lipogenic enzymes (FAS, Fatty acid synthetase; G6PD, Glucose-6-phosphate dehydrogenase; ME, Malic enzyme) in trial 2. Each symbol represents one individual. Straight lines represent a linear correlation between daily fat intake and G6PD, FAS or ME activity $(n=24)$.

the activity of G6PD was significantly higher (2 to 3 fold) than that of ME. G6PD activity (expressed as IU per mg protein or per $100 \mathrm{~g}$ of whole fish) was significantly affected by the dietary lipid level, with enhanced activities in fish fed the T15 diet compared to those fed the other diets. G6PD activity (expressed as IU per $g$ liver) was also found to be negatively correlated with fat intake (Fig. 2) and positively correlated with starch intake $(r=0.73, P<0.0001)$. Malic enzyme and FAS activities were notsignificantly different $(P>0.05)$ among dietary treatments, but expressed as IU per g liver, they were negatively correlated to fat intake (Fig. 2) and positively correlated to starch intake $(r=0.42, P=0.04$ and $r=0.48, P=0.02$ respectively).

\section{DISCUSSION}

In the present study, rainbow trout fed either on demand by means of self-feeders (trial 1) or by hand to satiation (trial 2) tended to adjust their daily feed intake to digestible energy content, in agreement with earlier findings [31, 54, 58, 63]. Very early, Kaushik et al. [59] and Kaushik and Luquet [57] found that in rainbow trout, the voluntary feed intake was controlled by the availability of energy. However, in hand-fed trout, the compensation of lower dietary lipid levels (T15 and T20 diets) by an increase in feed intake was not sufficient to reach the same amount of daily DE intake as with a higher dietary lipid content (T25 and T30). Alanärä [3] and Alanärä and Kiessling [4] did not find any significant relation between dietary energy content and demandfeeding activity for rainbow trout and Arctic charr (Salvelinus alpinus), respectively. These authors suggested that the difference in energy content between the diets they used $\left(1.2 \mathrm{~kJ} \cdot \mathrm{g}^{-1} \mathrm{DM}\right)$ was too small to induce any regulation of feeding activity. In agreement with this, in the present study, significant changes in feeding activity were detected when the difference between dietary digestible energy contents was at least $2.2 \mathrm{~kJ} \cdot \mathrm{g}^{-1} \mathrm{DM}$. However, in small Atlantic salmon, Salmo salar, the difference 


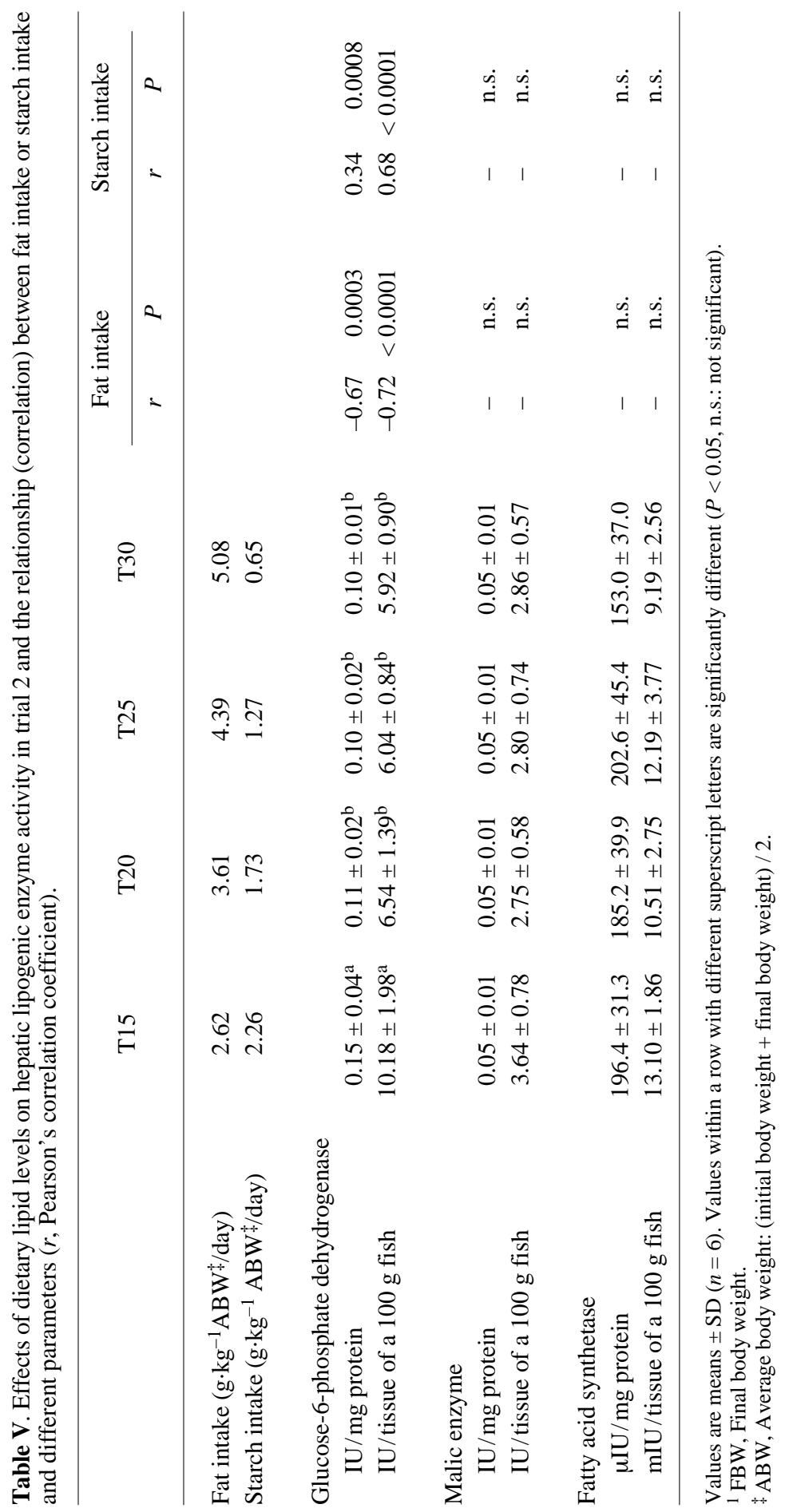


required in dietary energy content to obtain significant variations in voluntary feed intake was only $1.1 \mathrm{~kJ} \cdot \mathrm{g}^{-1} \mathrm{DM}$ [74].

In pigs, the energy density of the diet has been shown to affect feed intake [70]. Cole et al. [24] suggested that pigs eat enough for constant digestible energy, except when a low energy diet limits intake physically, or when very high density diets are ingested in greater quantities to avoid an under filled stomach, inducing hyperphagia. According to Colgan [25], stomach fullness should be responsible for short-term feed intake regulation in fish. A recent study with European sea bass [34] showed that the dietary dilution with bulk agents increases VFI, but when corrected for nutrient dilution, VFI expressed per unit of body weight remains constant. It cannot therefore be excluded that regulation of food intake, when animals are fed with diets of extremely low or extremely high energy density, may be partially mediated through the control of gastric emptying [62].

Our study confirms the existence of a positive effect of high dietary energy contents on feed efficiency and protein efficiency ratio as already described in the rainbow trout $[10,15,55,58,63]$. In hand-fed trout, FE and PER were respectively enhanced by $11 \%$ and $7.5 \%$ from $15 \%$ to $30 \%$ dietary lipid contents, whereas in selffed trout, this rise was more evident (14\% for FE and $18 \%$ for PER). It can be assumed that these differences between the two trials are not only due to the feeding method, but also to fish size (the fish used in trial 1 were smaller than those used in trial 2), the maintenance and growth components of protein requirements changing with increasing body size.

In accordance with earlier data in rainbow trout with a wide range of sizes [55, $58,63,76,86]$, our data confirmed the existence of a fattening effect of fat enriched diets on the liver, viscera and also muscle in large rainbow trout. Of these different tissues, the viscera were more affected by dietary lipid levels than the muscle or liver as reported earlier $[44,81,86,91]$. The increase in viscera and muscle fat contents were responsible respectively for $63 \%$ and $37 \%$ of the increase of whole body fat contents between the T15 and T30 diets.

Whether such differences in fat deposition are due to changes in adipose cell size or in adipose cell number have so far not been clearly known. A few studies suggest that, in large rainbow trout, both hypertrophy and hyperplasia of adipose cells coexist in response to changes in ration size, dietary lipid sources or thermal conditions $[11,35]$. To our knowledge, this is the first observation that visceral adipose tissue is affected by the dietary lipid level and furthermore in an age- or size-dependant manner. Although literature data in fish are scarce, Fauconneau et al. [35] observed relatively higher proportions of small adipocytes $(<30 \mu \mathrm{m})$ in large trout $(630 \mathrm{~g})$ than in young trout $(110 \mathrm{~g})$. In our study, irrespective of the dietary treatment, small adipocytes $(<50 \mu \mathrm{m})$ were also more frequent in large trout (19 to $33 \%$ ) than in young trout (5 to $14 \%$ ), showing continuous recruitment.

In mammals, it is generally admitted that the number of cells in adipose tissues is fixed early in development $[14,64]$ and a further increase in adipose tissue mass is mainly due to hypertrophy. However, in adults, several studies have revealed the existence of a hyperplasic growth of adipose tissue in response to fat or carbohydrate enriched diets $[2,36,37,65]$. In young trout (75 g), increased dietary lipid content generated an increase in the frequency of small $(<50 \mu \mathrm{m})$ and middle-sized (50-150 $\mu \mathrm{m})$ adipose cells and a consequent fall in the proportion of larger adipocytes (> $150 \mu \mathrm{m})$. In larger trout $(450 \mathrm{~g})$, the frequency of small cells decreased and that of large cells increased with elevated dietary lipid contents, without affecting the frequency of middle-sized adipocytes. It is suspected that the development of visceral adipose tissue related to fat enriched diets in trout might involve both 
hyperplasic and hypertrophic processes depending on the developmental stage. Our data suggest that the hyperplasic process is stimulated by fat enriched diets in young trout, consequently increasing the storage capacity of the adipose tissue, with a concomitant increase in cell size. In larger trout, the storage potentiality being already developed and higher than that of young trout, high dietary fat content induced hypertrophy of the existing small adipocytes.

Lipogenesis represents the final common fate for surplus non-fat energy and contributes to the macronutrient energy balance [42]. In pigs [73], ruminants [50, 53, 89], dogs [8] and cats [78], adipose tissue is the major site of de novo fatty acid synthesis. In rodents such as rats, mice and rabbits, both the adipose tissue and liver are important sites of lipogenesis [48, 66]. In man [48] and most avian species [45, 48], the liver is identified as the major contributor to fatty acid synthesis. In fish, most studies [7, 43, $67,68]$ have demonstrated the primary role of the liver in de novo fatty acid synthesis, adipose tissue being better adapted for storage of dietary lipids or neo-synthesised fatty acids from the liver [23, 43].

Of the two NADPH-generating enzymes, malic enzyme (ME) activity was two-fold lower than that of glucose-6-phosphate dehydrogenase (G6PD), as earlier studies have also shown on coho salmon, rainbow trout and sea bass [33, 52, 68, 69, 90]. It can therefore be deduced that, in these species most cytoplasmic reducing equivalents (NADPH) come from the pentose-phosphate pathway.

Lipogenic enzyme activities in the trout liver revealed that G6PD, FAS and to a lesser extent ME activities were depressed when diets passed from a high carbohydrate level (diet T15) to a high fat level (diet T30). Liver G6PD activity was 1.6 fold higher in trout fed the lower lipid content diet, which was also richer in total starch (14\% DM), than in those fed the $30 \%$ lipid diet (containing 4.4\% DM starch). Liver ME activity was found to be only slightly negatively correlated with fat intake and positively to starch intake, but, as previously observed by Walzem et al. [90], changes in ME activity were also found to be correlated with growth rate, which was more responsible for these variations than dietary treatments. FAS activity was negatively correlated with fat intake but starch intake was shown to be the most important factor affecting FAS activity $(r=0.48, P=0.02)$.

The inhibitory effects of high dietary lipid level on lipogenic enzyme activities have been reported in several teleost species $[6$, $56,67,68,75,82,83$ ]. However, in contrast to most mammals in which de novo lipogenesis is inhibited even by small increases in dietary fat [20], in fish this is only obvious when dietary lipid content exceeds $10 \%$ [43, 67]. Our results on FAS activity confirm that the regulation of lipogenesis by dietary fat is less severely controlled in trout than in other animals.

Carbohydrate-rich diets stimulated enzymes involved in the lipogenic pathway in mammals $[48,88]$. Similarly, our results confirmed this stimulatory effect of high dietary carbohydrates on lipogenic enzyme activity in rainbow trout, as previously reported in the same species [49] and in other teleost species $[27,32,39,67,82,83]$.

These effects of dietary carbohydrate and/or lipids on lipogenic enzyme activities have been recently confirmed in vitro by studies on trout hepatocytes [5].

In conclusion, although optimal use of high energy diets can increase protein efficiency and despite the adaptive response of rainbow trout to high-fat diets through (1) maintenance of energy intake up to values of $20.5 \mathrm{~kJ} \mathrm{DE} \cdot \mathrm{g}^{-1}$ diet, (2) increased utilisation of lipids for energy purposes and (3) reduction of hepatic lipogenesis, trout continued depositing in order to maintain the chemical composition of their wholebody and tissues. Simply stated, feeding trout a high fat diet produced fatter fish, with lipid deposition being primarily in the 
visceral cavity and to a lesser extent in the muscle. Since the development with age of adipose tissue is correlated with a recruitment of pre-adipocytes, an increased storage capacity by dietary manipulations results from hyperplasic and hypertrophic processes in trout. Besides, the use of a high fat diet depresses de novo fatty acid synthesis and increases lipid storage of dietary origin. Therefore, a high quality dietary lipid profile may impair the nutritional value of fish flesh as human food.

\section{ACKNOWLEDGEMENTS}

The first author benefited from a CIFRE scholarship partly funded by the French Ministry of Research and Higher Education. This study was financially supported by the European Community project "Gutintegrity" \# Q5RS-200031656 and by the Conseil Régional d'Aquitaine.

\section{REFERENCES}

[1] Ackman R.G., Composition and nutritional value of fish and shellfish lipids, in: Ruiter A. (Ed.), Fish and Fisheries Products. Composition, Nutritive properties and stability, CAB International, Wallingford, Oxon., UK, 1995, pp. 117-156.

[2] Ailhaud G., Amri E., Bertrand B., BarcelliCouget S., Bardon S., Cellular and molecular aspects of adipose tissue growth, in: Bray G., Ricquier D. Spiegelman B. (Eds.), Obesity Towards a Molecular Approach, Liss, New York, 1990, pp. 219-236.

[3] Alanärä A., The effect of temperature, dietary energy content and reward level on the demand feeding activity of rainbow trout (Oncorhynchus mykiss), Aquaculture 126 (1994) 349-359.

[4] Alanärä A., Kiessling A., Changes in demand feeding behaviour in Arctic charr Salvelinus alpinus L., caused by differences in dietary energy content and reward level, Aqua. Res. 27 (1996) 479-486.

[5] Alvarez M.J., Diez A., Lopez-Bote C.J., Gallego M., Bautista J.M., Short-term modulation of lipogenesis in rainbow trout (Oncorhynchus mykiss) hepatocytes, Br. J. Nutr. 84 (2000) 619-628.

[6] Arnesen P., Krogdahl Å., Kristiansen I.Ø., Lipogenic enzyme activities in liver of Atlantic salmon (Salmo salar, L.), Comp. Biochem. Physiol. B 105 (1993) 541-546.
[7] Aster P.L., Moon T.W., Influence of fasting and diet on lipogenic enzymes in the American eel, Anguilla rostrata LeSueur, J. Nutr. 111 (1981) 346-354.

[8] Baldner G.L., Flatt R.E., Shaw R.N., Beitz D.C., Fatty acid biosynthesis in liver and adipose tissue from dogs, Comp. Biochem. Physiol. B 82 (1985) 153-156.

[9] Bautista J.M., Garrido-Pertierra A., Soler G., Glucose-6-Phosphate dehydrogenase from Dicentrarchus labrax liver: kinetic mechanism and kinetics of NADPH inhibition, Biochim. Biophys. Acta 967 (1988) 354-363.

[10] Beamish F.W.H., Medland T.E., Protein sparing effects in large rainbow trout, Salmo gairdneri, Aquaculture 55 (1986) 35-42.

[11] Bellardi S., Bianchini M.L., Domenis L., Palmegiano G.B., Effect of feeding schedule and feeding rate on size and number of adipocytes in rainbow trout Oncorhynchus mykiss, J. World Aquacult. Soc. 26 (1995) 80-83.

[12] Bergot F., Digestibility of native starch of various botanical origin by rainbow trout (Oncorhynchus mykiss), in: Kaushik S.J., Luquet P. (Eds.), Fish Nutrition in Practice, Versailles Cedex, France, 1993, vol. 61, pp. 857-866.

[13] Bergot F., Brèque J., Digestibility of starch by rainbow trout: effects of the physical state of starch and of the intake level, Aquaculture 34 (1983) 203-212.

[14] Björntorp P., Development of adipose tissue in vivo and in vitro, in: Angel A., Wollenberg C.H., Roncari D.A.K. (Eds.), The Adipocyte and Obesity: Cellular and Molecular Mechanism, Raven Press, New York, USA, 1983, pp. 33-39.

[15] Boujard T., Médale F., Regulation of voluntary feed intake in juvenile rainbow trout fed by hand or by self-feeders with diets containing different protein / energy ratios, Aquat. Living Resour. 7 (1994) 211-215.

[16] Boujard T., Dugy X., Genner D., Gosset C., Grig G., Description of a modular, low cost, eater meter for the study of feeding behaviour and foods preferences in fish, Physiol. Behav. 52 (1992) 1101-1106.

[17] Bradford M., A rapid and sensitive method for the quantification of microgram quantities of protein utilising the principle of protein-dye binding, Anal. Biochem. 72 (1976) 248-254.

[18] Brauge C., Corraze G., Médale F., Effects of dietary carbohydrate levels on growth, body composition and glycaemia in rainbow trout, Oncorhynchus mykiss, reared in seawater, Aquaculture 123 (1994) 109-120.

[19] Brauge C., Corraze G., Médale F., Effects of dietary levels of carbohydrate and lipid on glucose oxidation and lipogenesis from glucose in rainbow trout, Oncorhynchus mykiss, reared in freshwater or in seawater, Comp. Biochem. Physiol. A 111 (1995) 117-124. 
[20] Chilliard Y., Dietary fat and adipose tissue metabolism in ruminants, pig and rodents: a review, J. Dairy Sci. 76 (1993) 3897-3931.

[21] Cho C.Y., Feeding systems for rainbow trout and other salmonids with reference to current estimates of energy and protein requirements, Aquaculture 100 (1992) 107-123.

[22] Cho C.Y., Kaushik S.J., Nutritional energetics in fish: energy and protein utilization in rainbow trout (Salmo gairdneri), World Rev. Nutr. Diet. 61 (1990) 132-172.

[23] Christiansen D.C., Skarstein L., Klungs øyr L., Uptake studies in adipocytes isolated from rainbow trout (Salmo gairdneri). A comparison with adipocytes from rat and cat, Comp. Biochem. Physiol. A 82 (1985) 201-205.

[24] Cole D.J.A., Hardy B., Lewis D., Nutrient density in pig diet, in: Cole D.J.A. (Ed.), Pig Production, Butterworths, London, UK, 1972, pp. 243-257.

[25] Colgan P., Motivational analysis of fish feeding, Behaviour 45 (1973) 38-67.

[26] Corraze G., Nutrition lipidique des poissons : importance et conséquences, Pisc. Fr. 117 (1994) 25-36.

[27] Corraze G., Aires T., Médale F., Dietary starch levels affect the activities of enzymes involved in lipogenesis in gilthead sea bream, in: Proceedings of the VIIIth International Symposium on Nutrition and Feeding in Fish, Recent Advances in Finfish \& Crustacea Nutrition, Las Palmas de Gran Canaria, Spain, 1998, p. 56.

[28] Cowey C.B., Some effects of nutrition on flesh quality of cultured fish, in: Kaushik S.J., Luquet P. (Eds.), Fish Nutrition in Practice, Versailles Cedex, France, 1993, vol. 61, pp. 227-236.

[29] Cowey C.B., Luquet P., Physiological basis of protein requirements of fishes, Critical evaluation of allowances, in: Kaushik S.J., Luquet P. (Eds.), Fourth International Symposium on Protein Metabolism and Nutrition, Versailles Cedex, France, 1983, vol. 16, pp. 365-384.

[30] Cuenca E.M., Diz L.G., De La Higuera M., Selfselection of a diet covering zinc needs in the trout, in: Kaushik S.J., Luquet P. (Eds.), Fish Nutrition in Practice, Versailles Cedex, France, 1993, vol. 61, pp. 413-418.

[31] Davies S.J., Comparative performance of juvenile rainbow trout, Salmo gairdneri Richardson, fed to satiation with simulated «standard» and "high energy" diet formulations, Aquac. Fish. Manage. 20 (1989) 407-416.

[32] De Silva S.S., Gunasekera R.M., Shim K.F., Interactions of varying dietary protein and lipid levels in young red tilapia: evidence of protein sparing, Aquaculture 95 (1991) 305-318.

[33] Dias J., Alvarez M.J., Diez A., Arzel J., Corraze G., Bautista J.M., Kaushik S.J. Regulation of hepatic lipogenesis by dietary protein/ energy in juvenile European seabass (Dicentrarchus labrax), Aquaculture 161 (1998) 169-186.
[34] Dias J., Huelvan C., Dinis M.T., Métailler R., Influence of dietary bulk agents (silica, cellulose and a natural zeolite) on protein digestibility, growth, feed intake and feed transit time in European seabass (Dicentrarchus labrax) juveniles, Aquat. Living Resour. 11 (1998) 219-226.

[35] Fauconneau B., André S., Chmatilly J., Le Bail P.-Y., Krieg F., Kaushik S.J., Control of skeletal muscle fibres and adipose cells size in the flesh of rainbow trout, J. Fish Biol. 50 (1997) 296-314.

[36] Faust I.M., Miller W.H., Hyperplastic growth of adipose tissue in obesity, in: Angel A., Wollenberg C.H., Roncari D.A.K. (Eds.), The Adipocyte and Obesity: Cellular and Molecular Mechanism, Raven Press, New York, USA, 1981, pp. 41-51.

[37] Faust I.M., Johnson P.R., Stern J.S., Hirsch J., Diet-induced adipocyte number increase in adult rats: a new model of adiposity, Am. J. Physiol. 235 (1978) E275-E286.

[38] Folch J., Lees M., Sloane-Stanley G.H.S., A simple method for the isolation and purification of total lipids from animal tissues, J. Biol. Chem. 226 (1957) 497-509.

[39] Fynn-Aikins K.H.S., Liu W., Li H., Growth, lipogenesis and liver composition of juvenile white sturgeon fed different levels of D-glucose, Aquaculture 105 (1992) 61-72.

[40] Gallego M.G., Hidalgo M.C., Suarez M.D., Sanz A., Feeding of the European eel Anguilla anguilla. II. Influence of dietary lipid level, Comp. Biochem. Physiol. A 105 (1993) 171-175.

[41] Grove D.J., Loizides L.G., Nott J., Satiation amount, frequency of feeding and gastric emptying rate in Salmo gairdneri, J. Fish Biol. 12 (1978) 507-516.

[42] Hellerstein M.K., Christiansen M., Kaempfer S., Kletke C., Wu R., Reid J.S., Mulligan K., Hellerstein N.S., Shackleton C.H., Measurement of de novo hepatic lipogenesis in humans using stable isotopes, J. Clin. Invest. 87 (1991) 1841-1852.

[43] Henderson R.J., Sargent J.R., Lipid biosynthesis in rainbow trout, Salmo gairdneri, fed diets differing in lipid content, Comp. Biochem. Physiol. C 69 (1981) 31-37.

[44] Henderson R.J., Tocher D.R., The lipid composition and biochemistry of freshwater fishes, Prog. Lipid Res. 26 (1987) 281-347.

[45] Herzberg G.R., Rogerson M., Tissue distribution of lipogenesis in vivo in the common murre (Uria aalge) and the domestic chicken (Gallus domesticus), Comp. Biochem. Physiol. B 96 (1990) 767-769.

[46] Hidalgo F., Kentouri M., Divanach P., Sur l'utilisation du self-feeder comme outil d'épreuve nutritionnelle du loup, Dicentrarchus labraxRésultats préliminaires avec la méthionine, Aquaculture 68 (1988) 177-190. 
[47] Hillestad M., Johnsen F., High energy/low protein diets for Atlantic salmon: effects on growth, nutrient retention and slaughter quality, Aquaculture 124 (1994) 109-116.

[48] Hillgartner F.B., Salati L.M., Goodridge A.G., Physiological and molecular mechanisms involved in nutritional regulation of fatty acid synthesis, Physiol. Rev. 75 (1995) 47-76.

[49] Hilton J.W., Atkinson J.L., Response of rainbow trout (Salmo gairdneri) to increasing levels of available carbohydrate in practical trout diets, Br. J. Nut. 47 (1982) 597-607.

[50] Hood R.L., Cook L.J., Mills S.C., Scott T.W., Effect of feeding protected lipids on fatty acid synthesis in ovine tissues, Lipids 15 (1980) 644-654.

[51] Hsu R.Y., Butterworth P.H.W., Porter J.W., Pigeon liver fatty acid synthetase, in: Lowenstein J.M. (Ed.), Methods in Enzymology, Academic Press Inc, New York, USA, 1969, Vol. 14, pp. 33-39.

[52] Hung S.S.O., Storebakken T., Carbohydrate utilization by rainbow trout is affected by feeding strategy, J. Nutr. 124 (1994) 223-230.

[53] Ingle D.L., Bauman D.E., Garrigus U.S., Lipogenesis in the ruminant: in vivo site of fatty acid synthesis in sheep, J. Nutr. 102 (1972) 617-624.

[54] Jobling M., Wandsvik A., An investigation of factors controlling food intake in Arctic charr, Salvelinus alpinus L, J. Fish Biol. 23 (1983) 397-404.

[55] Jobling M., Koskela J., Savolainen R., Influence of dietary fat level and increased adiposity on growth and fat deposition in rainbow trout, Oncorhynchus mykiss (Walbaum), Aqua. Res. 29 (1998) 601-607.

[56] Jürss K., Bittorf T., Völker T., Influence of salinity and ratio of lipid to protein in diets on certain enzyme activities in rainbow trout (Salmo gairdneri Richardson), Comp. Biochem. Physiol. B 81 (1985) 73-79.

[57] Kaushik S.J., Luquet P., Relationship between protein intake and voluntary energy intake as affected by body weight with an estimation of maintenance needs in rainbow trout, $Z$. Tierphysiol. Tierernähr. U. Futturmittelkunde 51 (1983) 57-69.

[58] Kaushik S.J., Oliva-Teles A., Effect of digestible energy on nitrogen and energy balance in rainbow trout, Aquaculture 50 (1985) 89-101.

[59] Kaushik S.J., Luquet P., Blanc D., Usefulness of feeding protein and non protein calories apart in studies on energy protein interrelationships in rainbow trout, Ann. Zootech. 30 (1981) 411-424.

[60] Kaushik S.J., Médale F., Fauconneau B., Blanc D., Effect of digestible carbohydrates on protein/energy utilisation and on glucose metabolism in rainbow trout (Salmo gairdneri R.), Aquaculture 79 (1989) 63-74.
[61] Kentouri M., Divanach P., Geurden I., Anthouard M., Mise en évidence du comportement adaptatif de la daurade (Sparus aurata, L.) en relation avec la composition de la ration, dans une situation de nourrissage auto-contrôle, Ichtyophysiol. Acta 18 (1993) 125-143.

[62] Le Bail P.-Y., Boeuf G., What hormones may regulate food intake in fish? Aquat. Living Resour. 10 (1997) 371-379.

[63] Lee D.J., Putnam G.B., The response of rainbow trout to varying protein/energy ratios in a test diet, J. Nutr. 112 (1973) 112-117.

[64] Lee Y.B., Kauffman R.G., Grummer R.H., Effect of early nutrition on the development of adipose tissue in the pig. 1. Age constant basis, J. Anim. Sci. 37 (1973) 1312-1318.

[65] Lemonier P., Effect of age, sex and site on the cellularity of the adipose tissue in mice and rats rendered obese by a high-fat diet, J. Clin. Invest. 51 (1972) 2907-2912.

[66] Leung T.T., Bauman D.E., In vitro studies of the pathways of fatty acid synthesis in the rabbit, Int. J. Biochem. 7 (1976) 7-12

[67] Likimani T.A., Wilson R.P., Effects of diet on lipogenic enzyme activities in channel catfish hepatic and adipose tissue, J. Nutr. 112 (1982) 112-117.

[68] Lin H., Romsos D.R., Tack P.I., Leveille G.A., Influence of dietary lipid on lipogenic enzyme activities in coho salmon (Oncorhynchus kisutch (Walbaum)), J. Nutr. 107 (1977) 846-854.

[69] Lin H., Romsos D.R., Tack P.I., Leveille G.A., Effects of fasting and feeding various diets on hepatic lipogenic enzyme activities in coho salmon (Oncorhynchus kisutch (Walbaum)), J. Nutr. 107 (1977) 1477-1483.

[70] National Research Council (NRC), Predicting Feed Intake of Food-Producing Animals, National Academic Press, Washington, DC, USA, 1987.

[71] National Research Council (NRC) Nutrient Requirements of Fish. National Academic Press, Washington, DC, USA, 1993.

[72] Ochoa S., Malic enzyme, in: Colowick S.P., Kaplan N.O. (Eds.), Methods in Enzymology, Academic Press Inc, New York, USA, 1955, Vol. 1, pp. 739-753.

[73] O'Hea E.K., Leveille G.A., Significance of adipose tissue and liver as sites of fatty acid synthesis in the pig and the efficiency of utilisation of various substrates for lipogenesis, J. Nutr. 99 (1969) 338-344.

[74] Paspatis M., Boujard T., A comparative study of automatic feeding and self-feeding in juvenile Atlantic salmon (Salmo salar) fed diet of two different energy levels, Aquaculture 145 (1996) 245-257.

[75] Poston H.A., McCarthney T.H., Effect of dietary biotin and lipid on growth, stamina, lipid metabolism and biotin-containing enzymes in 
brook trout (Salvelinus fontinalis), J. Nutr. 104 (1974) 315-322.

[76] Reinitz G.L., Orme L.E., Lemm C.A., Hitzel F.N., Influence of varying lipid concentrations with two protein concentrations in diets for rainbow trout (Salmo gairdneri), Trans. Am. Fish. Soc. 107 (1978) 751-754.

[77] Reyne Y., Teyssier J., Noughes J., Tebibel S., Longitudinal study of adipose cell size in the dorsocapular and perineal depots of the growing rabbit, J. Lipid Res. 26 (1985) 1036-1046.

[78] Richard M.J., Holch J.T., Beitz D.C., Lipogenesis in the liver and adipose tissue of the domestic cat (Felis domestica), Comp. Biochem. Physiol. B 93 (1989) 561-564.

[79] Robelin J., Cellularity of bovine adipose tissues: developmental changes from 15 to 65 percent mature weight, J. Lipid Res. 22 (1981) 452-457.

[80] Robert N., Le Gouvello R., Mauviot J.C., Arroyo F., Aguirre P., Kaushik S.J., Use of extruded diets in intensive trout culture: effects of protein to energy ratios on growth, nutrient utilization and on flesh and water quality, in: Kaushik S.J., Luquet P. (Eds.), Fish Nutrition in Practice, Versailles Cedex, France, 1993, Vol. 61, pp. 497-500.

[81] Sheridan M.A., Regulation of lipid metabolism in poikilothermic vertebrates, Comp. Biochem. Physiol. B 107 (1994) 495-508.

[82] Shimeno S., Takeda M., Takayama S., Fukui A., Sasaki H., Kajiyama H., Adaptation of hepatopancreatic enzymes to dietary carbohydrates in carp, Bull. Jpn. Soc. Sci. Fish. 47 (1981) 71-77.

[83] Shimeno S., Kheyyali D., Shikata M., Metabolic response to dietary lipid to protein ratios in common carp, Fish. Sci. 61 (1995) 977-980.
[84] Smith R.R., Rumsey G.L., Scott M.L., Heat increment associated with dietary protein, fat, carbohydrates and complete diets in salmonids: Comparative energetic efficiency, J. Nutr. 108 (1978) 1025-1032.

[85] Spannhof L., Plantikow H., Studies on carbohydrates digestion in rainbow trout, Aquaculture 30 (1983) 95-108.

[86] Takeuchi T., Watanabe T., Ogino C., Supplementary effect of lipids in a high protein diet for rainbow trout, Bull. Jpn. Soc. Sci. Fish. 44 (1978) 677-681.

[87] Thivend P., Mercier C., Guilbot A., Determination of starch with glucoamylase. in: Whistler R.L., Bemiller J.N. (Eds.), Methods in Carbohydrate Chemistry, Academic Press Inc, New York, USA, 1972, Vol. VI, pp. 100-105.

[88] Towle H.C., Kaytor E.N., Shih H.M., Regulation of the expression of lipogenic enzyme genes by carbohydrate, Annu. Rev. Nutr. 17 (1997) 405-433.

[89] Vernon R.G., Lipid metabolism in the adipose tissue of ruminant animals, in: Christie W.W. (Ed.), Lipid Metabolism of Ruminant Animals, Pergamon Press, Oxford, UK, 1981, p. 279.

[90] Walzem R.L., Storebakken T., Hung S.S.O., Hansen R.J., Relationship between growth and selected enzyme activities of individual rainbow trout, J. Nutr. 121 (1991) 1090-1098.

[91] Watanabe T., Lipid nutrition in fish, Comp. Biochem. Physiol. B 73 (1982) 3-15.

[92] Wilson R.P., Amino acids and protein, in: Halver J.E. (Ed.), Fish Nutrition, Academic Press Inc, San Diego, USA, 1988, pp. 112-152.

\footnotetext{
To access this journal online: www.edpsciences.org
} 